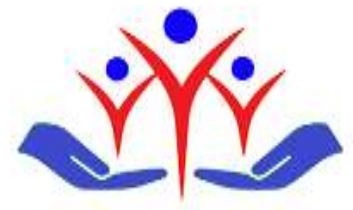

\title{
Macular and choroidal thickness of children with Familial Mediterranean Fever gene mutation
}

\author{
Ailevi Akdeniz Ateşi gen mutasyonu olan çocuklarda makula ve koroid kalınlıkları \\ Fatih Battal, (Dakan Aylanc ${ }^{\mathrm{a}}$, Sule Yildirim ${ }^{\mathrm{a}}$, (Deliz Ekim ${ }^{\mathrm{b}}$, (Datma Silan ${ }^{\mathrm{c}}$ (D) Ozturk Ozdemir \\ ${ }^{a}$ Canakkale Onsekiz Mart University, School of Medicine, Department of Pediatrics, Canakkale, Turkey \\ ${ }^{\mathrm{b}}$ Canakkale Onsekiz Mart University, School of Medicine, Department of Ophthalmology, Canakkale, Turkey \\ ${ }^{\mathrm{c}}$ Canakkale Onsekiz Mart University, School of Medicine, Department of Medical Genetics, Canakkale, Turkey
}

\begin{abstract}
Introduction: The present study aimed to evaluate macular and choroidal thicknesses in children with MEFV gene mutations.

Methods: Thirty-five children with MEFV gene mutations and 40 healthy controls were included in the study. MEFV gene profiles for the current cohort were genotyped by Pyrosequencing and direct Sanger sequencing techniques. The thicknesses of the macular and choroid of each subject's right eye were measured using spectral-domain optic coherence tomography.

Results: Mean arteriolar and venular diameters were $95.75 \pm 11.98 \mu \mathrm{m}$ and $127.61 \pm 10.44 \mu \mathrm{m}$ in children with the MEFV gene mutations and $110.19 \pm 11.10 \mu \mathrm{m}$ and $138.54 \pm 10.04 \mu \mathrm{m}$ in control group respectively. Children with the MEFV gene mutations were found to have a significantly less mean arteriolar diameter $(\mathrm{p}<0.001)$, mean venular diameter $(\mathrm{p}<0.001)$, less macular thickness $(\mathrm{p}=0.016)$, and less choroidal thickness $(\mathrm{p}=0.014)$ compared to healthy controls.

Conclusion: Children with the MEFV gene mutations had narrowing of the retinal arterioles, retinal venules, and macular and choroidal thinning. Future studies should aim to investigate endothelial dysfunction in children with Familial Mediterranean Fever by non-invasive and effective methods. Keywords: Child, choroid, macular thickness, Familial Mediterranean Fever
\end{abstract}

$\ddot{O Z Z}$

Giriş: $\mathrm{Bu}$ çalışmanın amacı, MEFV gen mutasyonlu çocuklarda maküla ve koroid kalınlıklarının değerlendirilmesidir. Yöntem: MEFV gen mutasyonlu 35 çocuk ve kontrol grubu olarak 40 sağlıklı çocuk çalışmaya alındı. MEFV gen profilleri Pyrosequencing ve direct Sanger sequencing sekanslama teknikleri ile genotiplendirildi. Her bir hastanın sağ göz maküla ve koroid kalınlıkları spektral-alan optik koherens tomografi kullanılarak ölçüldü.

Bulgular: Ortalama arteriolar ve venüler çaplar sırasıly MEFV gen mutasyonu olan çocuklarda 95,75 $\pm 11,98 \mu \mathrm{m}$ ve $127,61 \pm 10,44 \mu \mathrm{m}, \mathrm{kontrol}$

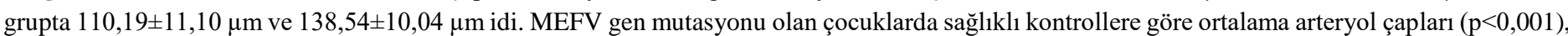
ortalama venüler çapları $(\mathrm{p}<0,001)$ daha ince idi ayrıca maküler kalınlık $(\mathrm{p}=0,016)$ ve koroid kalınlık $(\mathrm{p}=0,014)$ azalmıştı.

Sonuç: MEFV gen mutasyonları olan çocuklarda retinal arteriyollerin, retinal venüllerin ve maküler ve koroidal incelmenin olduğu görüldü. Gelecekteki çalışmalar, Ailesel Akdeniz Ateşi olan çocuklarda endotel disfonksiyonunu invazif olmayan ve etkili yöntemlerle araştırmayı amaçlamalıdır.

Anahtar Kelimeler: Çocuk, koroid, maküler kalınlık, Ailevi Akdeniz Ateşi

Submission: Dec 19, 2017

Acceptance: Mar 02, 2018

E-Mail: draylanc@ hotmail.com

Correspondence: Hakan Aylanc, MD

Canakkale Onsekiz Mart University, Faculty of Medicine, Department of Pediatrics, Canakkale, Turkey

www.fppc.com.tr 


\section{Introduction}

Familial Mediterranean Fever (FMF) is a hereditary disorder manifested by recurring attacks of arthritis, pleuritis and peritonitis, and evidenced by clinical, laboratory and histological, findings of localized and systemic inflammation. Ancient missense mutations in the Mediterranean Fever (MEFV) gene that alter structure and function of the pyrin protein have been found to cause FMF. The ability of pyrin to regulate inflammatory pathways is hindered by these alterations, which in turn leads to augmented or prolonged inflammation and predisposes FMF patients and MEFV mutation carriers to a proinflammatory state [1].

The choroid, the vascular layer between the retina and the sclera, contains connective tissue and supplies oxygen and nutrients to the outer retina. It plays a role in the pathophysiology of numerous diseases affecting the retina, including central serous chorioretinopathy, polypoidal choroidal vasculopathy, age-related macular degeneration and high myopia-related chorioretinal atrophies [2].

The vasculopathic nature and systemic inflammatory nature of FMF may lead to changes in retinal vascular diameters, macular and choroidal thicknesses. The number of studies about FMF patients with ocular diseases is limited in the literature with those that have been published being mostly case reports. The present study aimed to comparatively evaluate the retinal vascular diameters, macular and choroidal thicknesses of children with MEFV gene mutations.

\section{Methods}

The ethics committee of the Canakkale Onsekiz Mart University School of Medicine approved this prospective study. Children with MEFV gene mutations from October 2015 to February 2016 and healthy control subjects were recruited for the study. Informed consent from the parents of all children was obtained. Demographic data, such as age and gender, were obtained from a computerized patient database. Children were attack free for at least one week from the time of the study. A stadiometer (Seca 703, accurate to 100g, Seca GmBH\&Co Kg; Hamburg, Germany) was used for measurement of body weight and height by the same investigator (FB). Ophthalmic examinations were made by two independent investigator and included best-corrected visual acuity, axial length measurements, refraction, pneumatic tonometry, slit-lamp evaluation, and fundus examination. Patients with chronic diseases (e.g. DM, HT), neurological diseases, collagen vascular diseases, ocular disorders (e.g. myopia and astigmatism exceeding 1 diopters (D), hypermetropia exceeding 2 diopters (D), retinopathy of prematurity, glaucoma, nystagmus, strabismus, previous ocular trauma, history of ocular surgery, and children who were uncooperative for OCT scanning were excluded.

\section{Genotyping of target MEFV}

In a total of 35 children with minor and/or major FMF clinical findings with MEFV gene mutations total genomic DNA was extracted from peripheral blood samples with EDTA by using DNA isolation kit according to manufacturer's instructions (Roche, Germany). The genotyping of target $M E F V$ gene for each child from the current FMF cohort was made by Pyrosequencing and direct Sanger sequencing techniques. Patients were screened for common 22 point mutation profiles; E148Q, P369S, H478Y, F479L, S675N, G678E, M680L, M680I- G>A, M680I- G>C, T681I, I692del, M694V, M694L, M694I, K695R, K695M, R718S, I720M, V722M, V726A, A744S, R761H by Pyrosequencing analysis (Qiagene, Hilden/Germany). A small portion of patients who have FMF clinical findings without mutated profiles after Pyrosequensing were genotyped for exon 2 and 10 by direct sequencing analysis in the current cohort. The MEVF gene sequencing specific GLM kit (Switzerland) was used for that target exon genotyping. The PCR amplicons were purified and sequenced for both forward and revers strands by capillary electrophoresis technique in the current results (ABI Prism Genetic Analyser 3130, Applied Biosystem, USA).

\section{Patient group}

The right eyes of children with FMF gene mutations and control group were assessed. Measurement of retinal and choridal thicknesses and retinal vessels' diameters were evaluated by a spectral domain OCT device (Cirrus HD-OCT 4000; Carl Zeiss Meditec, Inc.). The diameters of the two largest retinal arterioles and venules passing through an area one-half to one-disc diameter from the optic disc margin were measured on OCT images using the calipers on the OCT device (Figure 1). The measurements were taken by two independent clinicians who were masked to the diagnosis and the values of the measurements were averaged for analysis [3].

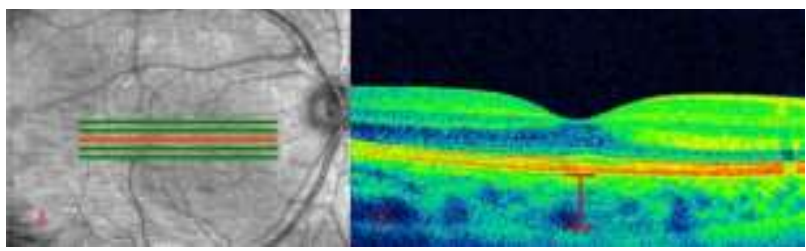

Figure 1. Enhanced depth imaging optical coherence tomography images (Cirrus HD-OCT 4000; Carl Zeiss Meditec Inc.) of a child in control group. (A) Technique for retinal vessel caliber measurements (B) Representative image of the measurement of subfoveal choroidal thickness. 


\section{Statistical Analysis}

SPSS software version 20.0 (SPSS Inc., Chicago, IL) was used for statistical analyses. The variables were evaluated using visual (histograms, probability plots) and analytical methods (Shapiro-Wilk's test) to determine whether or not they were normally distributed. According to tests of normality, either the Student's t-test or Mann-Whitney U-test was used to compare differences between children with MEFV mutations and healthy controls. Pearson correlation analysis was used to examine the relationship between anthropometric and retinal parameters in children with the MEFV gene mutations and control group.

\section{Results}

The anthropometric and ocular characteristics of 35 children with the MEFV gene mutations ( 19 of whom were boys) with a mean age of $11 \pm 4$ years (range, 7-15 years) and 40 children (23 boys) who served as a control group with a mean age of $11 \pm 5$ years (range, 6-16 years) are shown in Table 1. The distribution of MEFV gene mutations are as in Figure 2.

Table 1. Anthropometric and ocular characteristics of children with MEFV gene mutation and healthy controls.

\begin{tabular}{llll}
\hline Trait & $\begin{array}{l}\text { Children with the FMF } \\
\text { gene mutations (n:35) }\end{array}$ & Control (n:40) & P value \\
\hline Age,years & $11 \pm 4$ & $11 \pm 5$ & $N S$ \\
Sex male/female & $19 / 16$ & $23 / 17$ & $N S^{\#}$ \\
Weight,kg & $43(15-79)$ & $43(14-86)$ & $N S^{*}$ \\
Height,cm & $150(97-182)$ & $156.5(100-180)$ & $N S^{*}$ \\
Axial length,mm & $23.12(21.96-25.25)$ & $23.13(21.62-25.20)$ & $N S^{*}$ \\
\hline
\end{tabular}

\# Chi-Square. *Mann Whitney U Test. Significant $P$ value $<0.05$.

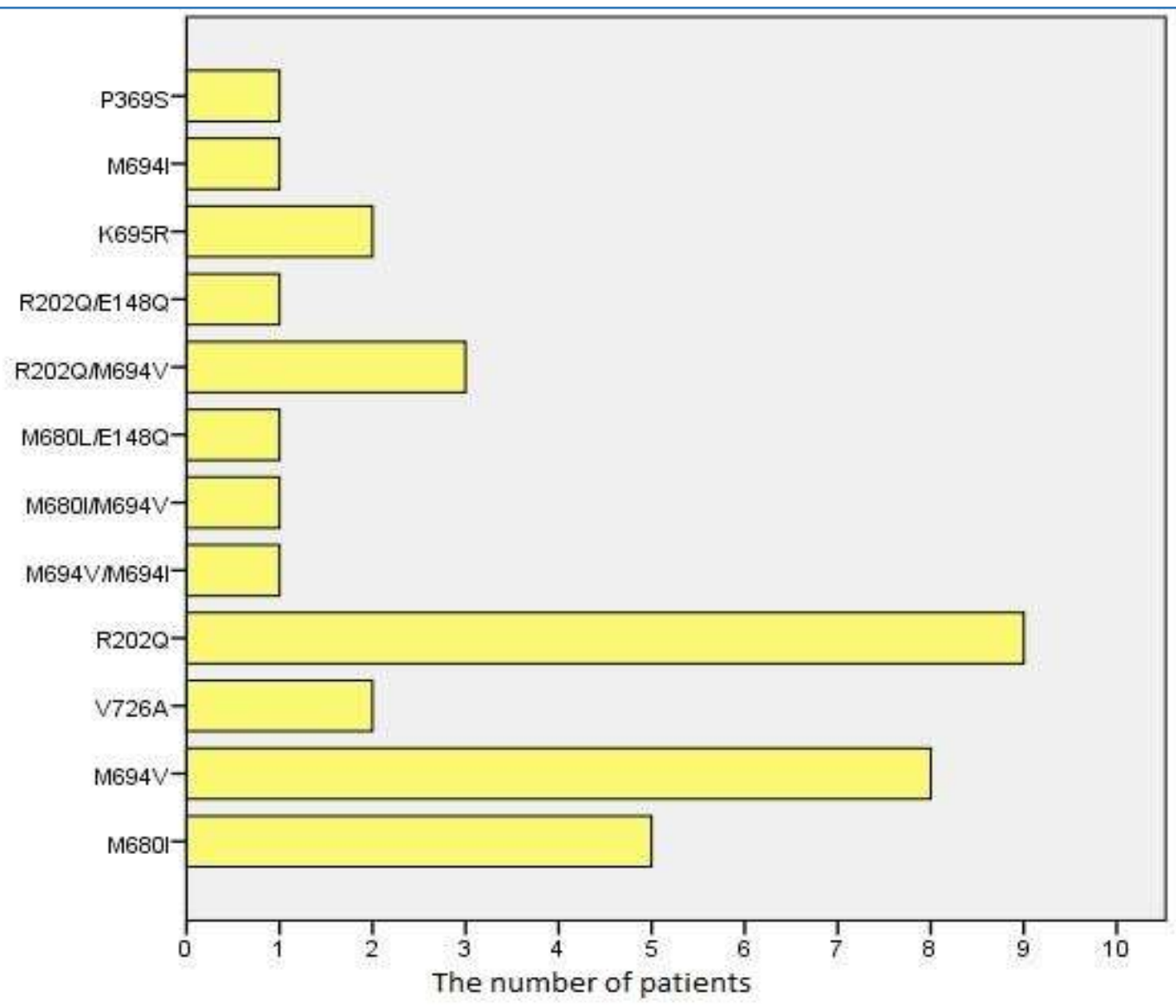

Figure 2. The MEFV gene mutation distribution of the patients. 
Children with the MEFV gene mutations were found to have a significantly less mean arteriolar diameter ( $\mathrm{p}<0.001)$, mean venular diameter $(\mathrm{p}<0.001)$, less macular thickness $(\mathrm{p}=0.016)$, and less choroidal thickness $(\mathrm{p}=0.014)$ compared to healthy controls (Table 2$)$.

Table 2. Retinal vascular diameters, choroidal and macular thicknesses of children with MEFV gene mutation and healthy controls.

\begin{tabular}{llll}
\hline Trait & $\begin{array}{l}\text { Children with the FMF gene mutations } \\
(\mathbf{n : 3 5})\end{array}$ & $\begin{array}{l}\text { Control patients } \\
(\mathbf{n : 4 0 )}\end{array}$ & P value * \\
\hline Mean arteriolar diameter, $\mu \mathrm{m}$ & $95.75 \pm 11.98$ & $110.19 \pm 11.10$ & $<0.001$ \\
Mean venular diameter, $\mu \mathrm{m}$ & $127.61 \pm 10.44$ & $138.54 \pm 10.04$ & $<0.001$ \\
Macular, $\mu \mathrm{m}$ & $232.23 \pm 32.24$ & $247.95 \pm 20.37$ & 0.016 \\
Choroidal thickness, $\mu \mathrm{m}$ & $270.54 \pm 50.91$ & $301.95 \pm 56.72$ & 0.014 \\
\hline
\end{tabular}

*Student t-test. Significant $P$ value $<0.05$.

\section{Discussion}

In the present study, choroidal and macular thickness, mean venular and arteriolar diameters were significantly less in children with MEFV gene mutations than in the healthy control group.

FMF is an inscrutable disorder not only consisted of typical attacks, but also with different atypical presentations, susceptibility to various diseases including vasculitis, and clinically silent but unhealthy carriers. It is now recognized that a mutated pyrin is related with the out-of-control inflammatory pathways, causing prolonged inflammation which predisposes these patients and the MEFV mutation carriers to a pro-inflammatory state. This increase in inflammation may result in predisposition to vascular comorbidities in patients and also in carriers of the MEFV mutation. The number of studied about FMF patients with ocular diseases is limited in the literature with those that have been published being mostly case reports. Ocular involvement is an infrequent complication in FMF patients. Previous publications on patients with FMF have reported double vision, blurred vision, necrotizing blepharitis, episcleritis, scleritis, optic disc vasculitis, bilateral panuveitis, anterior uveitis, bilateral disc edema, ptosis, tear film and ocular surface dysfunctions, ptosis, amaurosis fugax, oculomotor nerve palsy and markedly prolonged latencies of the visually evoked in these patients [4-8]. These findings are usually observed during acute FMF attacks. Majority of these involvements is of inflammatory origin.

It has been shown that FMF patients exhibit increased serum levels of TNF- $\alpha$ and IL-1 $\beta$ during acute attacks, and even in attack-free conditions [9, 10]. Recent studies have demonstrated that increased levels of TNF- $\alpha$ is associated with several ocular diseases. Elevated serum levels of TNF- $\alpha$ in diabetic patients having retinopathy might be an indication for retinopathy in all diabetics [11]. Numerous studies have shown a correlation between the serum levels of TNF- $\alpha$ and glaucomatous optic neuropathy. Increased levels of TNF- $\alpha$ resulted in oligodendrocytes and retinal ganglion cells damage in an animal model with high intraocular pressure. Cellular damage was also observed after administration of TNF- $\alpha$ without elevated intraocular pressure $[11,13]$. Sugita et al. found that the levels of TNF- $\alpha$ and TNF- $\alpha$ receptors were significantly increased in the ocular fluid of patients with active uveitis [14]. This means that subclinical inflammation persists during treatment, and even in remission. Based on this information, we aimed to determine whether the retinal structures of FMF patients in remission were affected by inflammation. In this study we found significant difference between the retinal structures of children with the FMF gene mutations and healthy controls.

In the only study investigating changes in the choroidal thickness in FMF patients by Erdurmus et al. [15] 30 children diagnosed with FMF in the attack-free period and 28 healthy control individuals were included and found statistically insignificant differences between the groups. Gündoğan et al. [16] demonstrated that the choroidal thickness at all predefined points was measured significantly thicker in FMF patients compared to the healthy controls during an acute attack. The results of that study suggest that an increase in the severity of the inflammatory reaction results in a related increase in the choroidal thickness in FMF patients. The vasculopathic nature and systemic inflammatory nature of FMF are likely to lead to exudation, increased vascular permeability and enlargement of the choroidal vessels during an acute attack, which in turn cause an increase in choroidal thickness. In the present study, we found a significant decrease in the macular thickness during the free attack period in children having MEFV gene mutations. Recent studies have demonstrated that the macular thickness is widely variable in the 6- to 17-year-old population and FMF patients exhibit increased serum levels of TNF- $\alpha$ and IL-1 $\beta$ during acute attacks, and even in attack-free conditions $[17,18]$. This means that subclinical inflammation persists during treatment, and even in remission. The macular thickness measured by OCT widely varies by age, gender, race, disc area, axial length and refractive error [19]. One percent of FMF patients also experience inflammatory bowel disease, Behcet disease or polyarteritis nodosa [20, 21]. Patients with clinically and genetically diagnosed FMF can also develop vasculitis [21]. In the present study, the finding of high prevalence of some MEFV mutations in Behçet disease provides a further genetic argument that MEFV may play a role in the expression of inflammatory disorders other than FMF.

Our study has some limitations. First, the biochemical parameters were not obtained in healthy children with a normal pediatric examination. Second, the data may not be representative of all children with the MEFV gene mutations. Another limitation is that it was a single center study and the sample size was relatively small. Further studies are needed to evaluate macular thickness and choroid thickness in children with the MEFV gene mutations using a larger sample size.

To our knowledge, this is the first study evaluating the effects of the MEFV gene mutations on retinal vascular diameters, macular and choroidal thicknesses in children. According to our results, children with the MEFV gene mutations had narrowing of the retinal arterioles, retinal venules, and 
less macular and choroidal thickness. Future researches should include investigation of the results of OCT and cutaneous laser Doppler flowmeter, which is widely accepted method of assessing endothelial dysfunction non-invasively in children. The combination of these methods may provide us microvascular assessment of children with the MEFV gene mutations.

Conflict of interest: none.

Funding: none.

\section{References}

1. Lachmann HJ, Sengul B, Yavuzsen TU, et al. Clinical and subclinical inflammation in patients with familial Mediterranean fever and in heterozygous carriers of MEFV mutations. Rheumatology. 2006;45(6):746-750. doi: https://doi.org/10.1093/rheumatology/kei279

2. Ikuno Y, Kawaguchi K, Nouchi T, et al. Choroidal thickness in healthy Japanese subjects. Invest Ophthalmol Vis Sci. 2010;51(4):2173-2176. doi: https://doi.org/10.1167/iovs.09-4383

3. Ersan I, Battal F, Aylanc H, et al. Noninvasive assessment of the retina and the choroid using enhanced-depth imaging optical coherence tomography shows microvascular impairments in childhood obesity. J AAPOS 2016;20(1):58-62. doi: https://doi.org/10.1016/j.jaapos.2015.10.006.

4. Akalin T, Demirag MD, Tezcan ME, et al. Scleritis and sudden hearing loss associated with familial Mediterranean fever. Clin Exp Rheumatol 2010;28(4 Suppl 60):S103-4.5. PMID:20868588

5. Akman A, Varan B, Akova YA, et al. Ocular involvement in siblings with familial mediterranean fever. J Pediatr Ophthalmol Strabismus 2000;38(2):114-116. PMID:11310705

6. Berestizschevsky S, Weinberger D, Avisar I, R. Avisar Episcleritias associated with familial Mediterranean fever. IMAJ. 2008;10(4):318-319. PMID: 18548993

7. Ozaltin F, Bakkaloglu A, Orhon M, et al. Bilateral uveitis in a 7-year-old patient with familial Mediterranean fever. An extremely rare complication. Clin Exp Rheumatol. 2001;19(5 Suppl 24):S80-1. PMID:11760412

8. Finsterer J, Stöllberger C, Shinar Y. Cranial nerve lesions and abnormal visually evoked potentials associated with the M694V mutation in familial Mediterranean fever. Clin Rheumatol 2002;21(4):317-321. doi: https://doi.org/10.1007/s100670200083

9. Direskeneli H, Ozdogan H, Korkmaz C, et al. Serum soluble intercellular adhesion molecule 1 and interleukin 8 levels in familial Mediterranean fever. J Rheumatol 1999;26:1983-1986. PMID:10493680

10. Baykal Y, Saglam K, Yilmaz M I, et al. Serum sIL-2r, IL-6,IL-10 and TNF-alpha level in familial Mediterranean fever patients. Clin Rheumatol 2003;22:99-101. doi: https://doi.org/10.1007/s10067-002-0682-1

11. Zorena K, Myśliwska J, Myśliwiec M, et al. Serum TNF-alpha level predicts nonproliferative diabetic retinopathy in children. Mediators Inflamm 2007;2007:92169. doi: https://doi.org/10.1155/2007/92196

12. Sawada H, Fukuchi T, Tanaka T, et al. Tumor necrosis factor-alpha concentrations in the aqueous humor of patients with glaucoma. Invest Ophthalmol Vis Sci 2010;51:903-906. doi: https://doi.org/10.1167/iovs.09-4247

13. Nakazawa T, Nakazawa C, Matsubara A, et al. Tumor necrosis factor-alpha mediates oligodendrocyte death and delayed retinal ganglion cell loss in a mouse model of glaucoma. J Neurosci 2006;26:12633-12641. doi: https://doi.org/10.1523/JNEUROSCI.2801-06.2006

14. Sugita S, Takase H, Taguchi C, et al. The role of soluble TNF receptors for TNF-alpha in uveitis. Invest Ophthalmol Vis Sci 2007;48:3246-3252. doi: https://doi.org/10.1167/iovs.06-1444

15. Erdurmus M, Bekdas M, Demircioglu F, et al. Retinal and choroidal thickness in children with familial Mediterranean fever. Ocul Immunol Inflamm 2014;22(6):444-448. doi: https://doi.org/10.3109/09273948.2014.916309

16. Gundogan FC, Akay F, Uzun S, et al. Choroidal Thickness Changes in the Acute Attack Period in Patients with Familial Mediterranean Fever. Ophthalmologica 2016;235(2):72-77. doi: https://doi.org/10.1159/000442216

17. Turk A, Ceylan OM, Arici C, et al. Evaluation of the nerve fiber layer and macula in the eyes of healthy children using spectral-domain optical coherence tomography. Am J Ophthalmol 2012;153(3):552-559. doi: https://doi.org/10.1016/j.ajo.2011.08.026

18. Baykal Y, Saglam K, Yilmaz M I, et al. Serum sIL-2r, IL-6,. Serum sIL-2r, IL-6, IL-10 and TNF-alpha level in familial Mediterranean fever patients. Clin Rheumatol 2003;22(2):99-101. doi: https://doi.org/10.1007/s10067-002-0682-1

19. El-Dairi MA, Asrani SG, Enyedi LB, et al. Optical coherence tomography in the eyes of normal children. Arch Ophthalmol 2009;127(1):50-58. doi: https://doi.org/10.1001/archophthalmol.2008.553

20. Birlik M, Tunca M, Hizli N, et al. Coexistence of familial Mediterranean fever with sacroiliitis and Behçet's disease: a rare occurrence. Clin Rheumatol 1998;17(5):397-399. PMID:9805187

21. Schwartz T, Langevitz P, Zemer D, et al. Behçet's disease in Familial Mediterranean fever: characterization of the association between the two diseases. Semin Arthritis Rheum 2000;29(5):286-295. PMID:10805353

22. Tekin M, Yalcinkaya F, Tumer N, et al. Clinical, laboratory and molecular characteristics of children with Familial Mediterranean Feverassociated vasculitis. Acta Paediatr 2000;89(2):177-182. doi: https://doi.org/10.1111/j.1651-2227.2000.tb01212.x 